Вісник Національного університету “Львівська політехніка”. Серія "Проблеми економіки та управління"

№ 2(8), 2020

УДК 656.078

JEL Classification: C81; M15; O32; R40

O. A. Pokhylchenko, I. V. Flyk

Lviv Polytechnic National University,

Department of Marketing and Logistics

\title{
DIGITALIZATION POTENTIAL OF LOGISTICS OPERATOR
}

http://doi.org/10.23939/semi2020.02.071

(C) Pokhylchenko O. A., Flyk I. V., 2020

The article investigates the methodological aspects of the management process in the field of the logistics customer services in terms of improving its digitalization potential. The phenomenon of digitalization has been studied insufficiently and, according to some foreign authors, it has significant potential for development from the theoretical perspective.

However, the digitalization of logistics in Ukraine is only gaining popularity in the scientific community. Consequently, a large number of domestic enterprises have certain difficulties while they are implementing innovations and digital solutions into the optimization of their activity. This actualizes the problems of this study as well as determines the aim and the practical tasks of the given article.

In particular, it has been determined that the potential for digitalization of logistics processes is manifested primarily in increasing the management quality and efficiency, the possibility of timely correction of threats and risks that arise, and in facilitating analytical processing and obtaining more accurate assessment of large amounts of information.

To identify the digitalization potential of the enterprise logistics, the article identifies the key changes that the logistics operator delivering goods within the territory of Ukraine based on the implementation of a range of digitalization tools may deal with.

Thus, the primary optimization measures taken in the process of implementing digitalization at the researched enterprise are the following: digitalization of document circulation at the enterprise, the process of loading and unloading delivery vehicles during the working day, the system of cargo placement in the warehouse. These measures will optimize various processes and reduce the influence of the human factor. Taken together, this will speed up the processes and increase the quality of their implementation by reducing the number of errors and delays.

To optimize intra-warehouse movements and the delivery process by digitalization of operating processes carried out by the logistics operator, it is advisable to prioritize the implementation of not only electronic document management system but also the following digital tools: RFID systems - for the efficient placement of goods in the warehouse and quick determination of their location, based on the use of RFID tags; GPS tracking - to increase the efficiency of vehicle use and reduce the cost of vehicle tracking, based on the use of GPS trackers; scale scanners as advanced weighing and measuring technologies that scan the load, determine its weight and volume, display the results and send them to the system.

The authors applied the AHP method to justify the application sequence of each technology and form an optimal digitalization plan as exemplified by the logistics operator under investigation. Using a multicriteria approach to assess the feasibility of implementing each digital solution based on the survey data, the respondents of which include company 
executives and experts of the considered domestic logistics operator, the optimal sequence of introducing digital technologies in this company has been identified.

Therefore, it is recommended to introduce the RFID system first. Then, the electronic document management should be launched. After that, it is recommended to introduce a scale scanner. Finally, the GPS system should be applied. Using the recommended algorithm for modeling the digitalization process and key changes that may occur at the investigated logistics operator resulting from digitalization tools set implementation, will allow domestic logistics operators to make optimal decisions. GPS system.

Key words: digital technologies, logistics customer services, AHP analysis, RFID system,

\section{Statement of the problem}

In today's world, one of the best and most effective ways to improve and enhance the efficiency of the enterprise is the digitalization of processes by using different technical innovations. Digitalization allows structuring the actions and steps of the enterprise on the way towards the use of the advanced technologies to optimize activities and get the most out of their implementation. At the same time, a large number of enterprises, including domestic ones, have certain difficulties in implementing and evaluating all risks and advantages of digital technologies to optimize their activities. This is due to insufficient research on the potential of digitalization, its methodology and the development of certain algorithms. The study of this phenomenon on the example of a domestic logistics operator will allow enterprises working in the field of logistics to more effectively use the potential of digitization.

\section{Analysis of recent research and publications}

The phenomenon of digitization is still insufficiently studied, but has significant methodological potential for development. Digitalization is a process of digital technology introduction into the activity for the increase of its efficiency. At the present stage of development of the economy of Ukraine, the applied aspect of digitalization, and hence, the analysis of recent research and publications on the outlined subject, have become especially relevant.

The aspects of the digital economy formation and development are covered in the works of such foreign researchers as P. Hagen, W. Isaacson, T. Scholz, A. Schwienbacher, B. Larralde, A. Toffler, $\mathrm{H}$. Toffler [1-5], who emphase the need and feasibility of using innovative solutions in business and management. In recent years, the managers, including L. Anderson, L. Heyden, V. Bamberger, B. Galinskaya, A. Magruk [6-9], have been actively researching the concept of digitalization in the logistics sector. In particular, they thoroughly investigated the following aspects: the effectiveness of digitalization of logistics processes, features of various digital technologies in the logistics sector, the prospects for digitalization of logistics in the near future.

The Ukrainian specialists, in particular Y. Bazhal, K. Kononova, N. Kraus, Ye. Krykavskyi and O. Pokhylchenko [10-15], have justified the conceptual approaches of digital economy, its role and perspectives.

Digitalization of logistics in Ukraine is only gaining popularity in the scientific community and is the most actively discussed among business practitioners. The digital economy is changing and new digital technologies emerge. This necessitates constant research into both existing and potential transformations.

\section{Formulation of objectives}

This article aims to study the theoretical and methodological aspects of managing the process of logistics customer services and justify the possibility of improving their digitalization potential. Achieving the goal will contribute to the development of recommendations for optimization of the enterprise logistics services based on the analysis of the digitalization possibilities as exemplified by "UKR Logist" Ltd, the logistics operator in the market of logistics. 


\section{Digitalization potential of logistics operator}

\section{Presenting of main material}

Due to the popularization of Internet resources in the world, e-commerce is developing rapidly, various business processes are changing and improving through the use of advanced digital technologies. Innovations allow companies to expand their potential significantly and ensure competitiveness in today's market. Besides, digital technologies optimize and improve the quality of enterprise activity, reduce execution time and costs of creating goods and services.

The introduction of digital technologies into the enterprise activity has been called "digitalization" and has recently developed its methodological potential significantly. Digitalization involves not only the selection and implementation of a particular technology in the enterprise, but causes changes in the organizational aspect of the enterprise management and adjustment of its ideology to the modern market requirements [16].

Digitalization is relevant to all the activities, including the logistics sector. After all, effective optimization of production, movement and sales requires a high level of information exchange among the participants of the logistics processes. The potential for digitalization of logistics processes is manifested primarily in the increase of the speed and efficiency of management, the possibility of timely correction of arising threats and risks, the facilitation of analytical processing and obtaining a more accurate assessment of large database of information [17].

The means of digitalization at the enterprise include:

- the use of the latest information processing technologies, such as electronic document management, big data, the Internet of Things, etc.;

- digitalization of individual operations, including logistics (tracking of vehicles, cargo, route formation, etc);

- optimization of the enterprise activity and management through arranging the cross-docking in warehouses, next day delivery, logistics of recycling;

- the use of modern technologies: drones, robots, artificial intelligence, RFID tags, GPS trackers, automated trucks, 3D printing.

- cooperation and collaboration with other companies: joint fleet, warehouse, crowdsourcing [16].

Therefore, to identify the digitalization potential of the logistics service processes, it is advisable to model key changes that may occur in the enterprise operating in the Ukrainian logistics services market under the conditions of implementing a set of measures aimed to introduce digitalization into the existing logistics operator under an assumed name "UKR Logist" Ltd (in order to preserve confidentiality in the article, the real name of the company is replaced by an invented name), which deals with the delivery of goods across the territory of Ukraine.

The detailed analysis of logistics processes and operations that take place at "UKR Logist" Ltd allows identifying "weaknesses" in the system of logistics customer service selected for the study of the enterprise (Fig. 1). These include the process of forming routes for each driver, the process of loading and unloading vehicles, as well as the systematization and placement of goods in the warehouse. It should also be noted that these operations are highly dependent on the the human factor as most operations involving the delivery of goods are performed manually. This often leads to confusion and errors in the placement of goods in the warehouse, the distribution between the directions of further transportation or between branches of the company. This actualizes the study of the digitalisation potential and implementation of new technologies to find the ways to solve the problems of failures and errors in the studied enterprise activity.

Thus, the primary measure involved in the process of launching digitalization at the enterprise under research is to choose digitalization of document circulation at the enterprise, the process of loading and unloading vehicles during delivery and handling during the working day, as well as the system of cargo placement in the warehouse. These measures will optimize various processes and reduce the influence of the human factor. Taken together, this will reduce the time of processes and increase the quality of their implementation by reducing the number of errors and delays (Fig. 2). 
To optimize intra-warehouse movements and the delivery process by digitalization, it is advisable to prioritize the implementation of the following digital tools:

1. Electronic document management will not only speed up delivery and handling time, but also eliminate the need to manually keep a large number of documents and their circulation in the company in paper form, which helps to preserve the environment, and eliminates the need for archives, as documents will be stored on servers or cloud resources.

2. RFID systems - for efficient placement of goods in the warehouse and quick determination of their location, based on the use of RFID tags. Such labels contain a microchip that will allow you to track the cargo in the online warehouse, and the system will indicate exactly where the cargo is. The RFID system will schematically divide the warehouse into sectors and indicate the point on the tablet, according to which the location of the desired cargo will be determined.

3. GPS tracking - to increase the efficiency of vehicle use and reduce the cost of vehicle tracking, based on the use of GPS-trackers, which will determine the location of the car and indicate it in the system. For this purpose, you can use a certain type of RFID tags.

4. Scanner scales as advanced weighing and measuring technologies that scan the load, determine its weight and volume, display the results and send them to the system. Also, to optimize the formation of routes, this process should be more automated. For example, the system automatically divides the city area taking into acount the number and the capacity of vehicles, and cargo is distributed according to different. The database contains all the data on the streets of each sector and possible transportation routes.

At the same time, the simultaneous implementation of all the suggested digital solutions is not only a technically difficult task, but also financially limited. Therefore, the next step is to justify the sequence of application of each technology and form an optimal plan for digitalization at "UKR Logist" Ltd. Since the implementation of a particular technology is not only quantitative, but also requires the qualitative expression of certain criteria, there is a need to apply multiple-criteria decision analysis (MCDA) to find the optimal digitalization plan.

Since 1960s MCDA has been extensively used in management science as a tool for evaluating options in decisions, which involve the achievement of multiple objectives [18]. There are variety of approaches and methods which are represented by different schools for solving MCDA problems. But in the case when the available criteria cannot be formalized in the form of specific criterion functions, but the expert can set his preferences based on pairwise comparison of the criteria and/or the alternatives in order to make the best decision among alternatives, the most appropriate ones are Analytic Hierarchy Process (AHP) and Analytic Network Process (ANP) [19].

According to [20-22] AHP and ANP are essentially ways to measure intangible factors in decisionmaking situations when subjectivity exists by using pairwise comparisons with judgments that represent the dominance of one element over another with respect to a property that they share. ANP is a more general approach, based on the description of the problem by means of a network instead of a hierarchy as in AHP. On the other hand, ANP is also more complex in its application (Table 1).

Thus, due to the fact that AHP is widely used in practice and is being actively developed by scientists all over the world, allows taking into account subjectivity exists to find an optimal solution, receives a positive assessment of people with the out coming priorities and at the same time requiring less costs and efforts comparing with ANP, the choice of AHP approach in this work seems to be more reasonable, and more preferable, given also the small number of analyzed alternatives.

Thus, to evaluate the feasibility of implementing each digital solution we have chosen the following criteria: cost of equipment, impact on efficiency, flexibility, controllability, reliability, system integration. The value and level of each criterion of the proposed digital technologies are based on the data obtained from a survey, the respondents of which include company executives and experts in the implementation of digital technologies into the business processes (Table 2). 
Digitalization potential of logistics operator

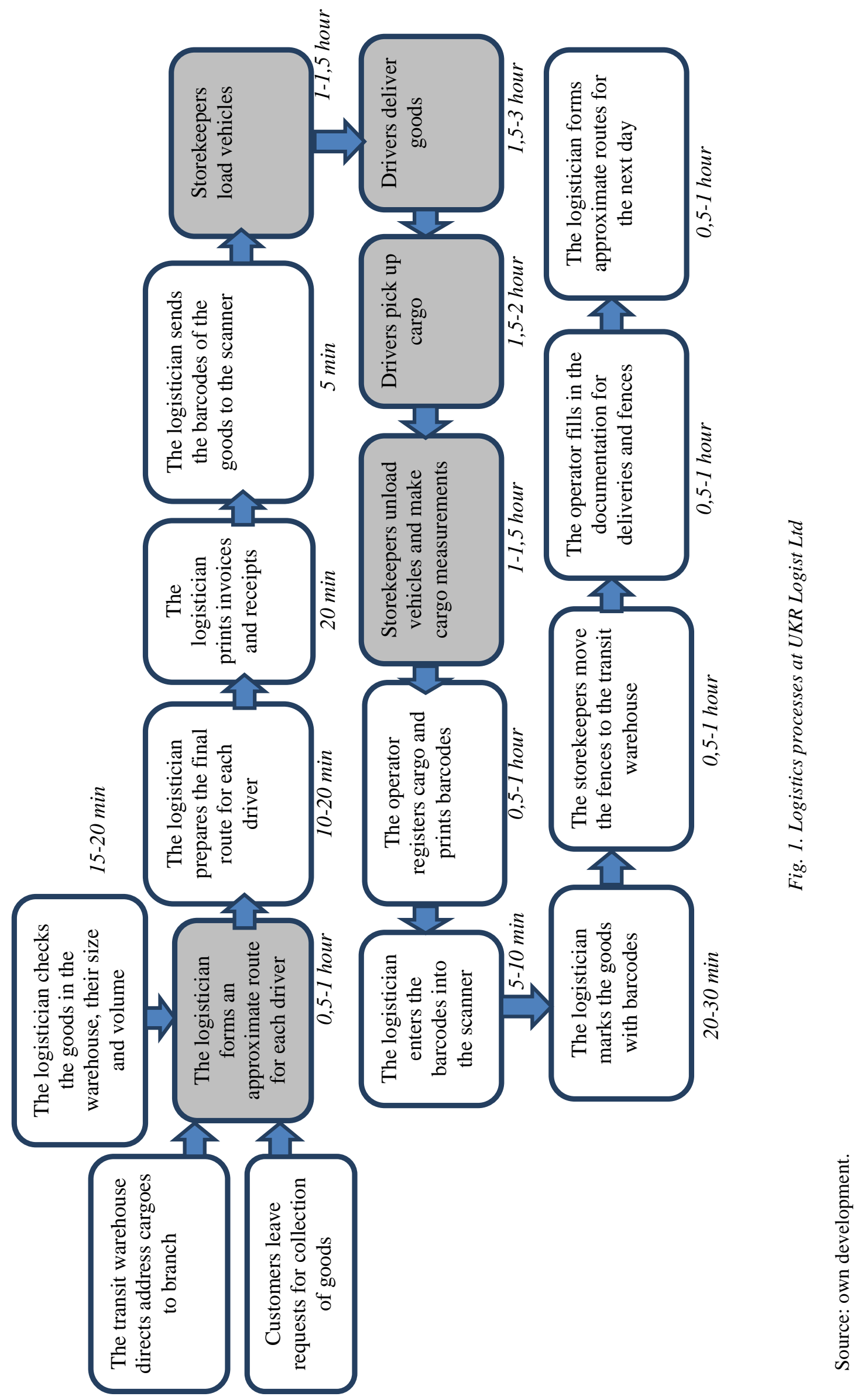




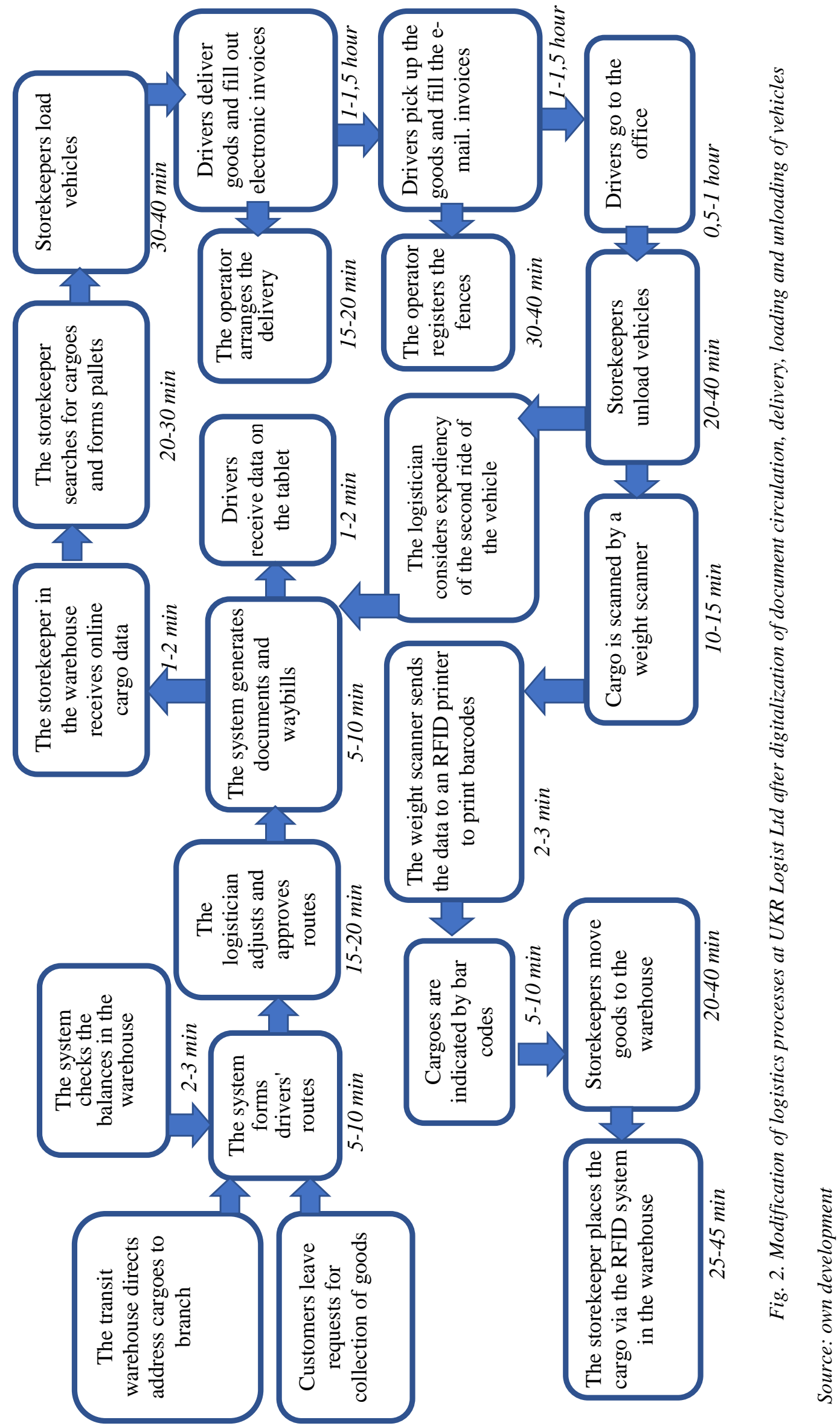


Comparing AHP and ANP: An Application of Multiple-criteria decision analysis (MCDA)

\begin{tabular}{|l|l|l|}
\hline \multicolumn{1}{|c|}{ Comparing elements } & \multicolumn{1}{|c|}{ AHP } & \multicolumn{1}{c|}{ ANP } \\
\hline $\begin{array}{l}\text { Variety of decision-making } \\
\text { situations where the method } \\
\text { works }\end{array}$ & $\begin{array}{l}\text { Wide variety of decision-making } \\
\text { situations which can be structured } \\
\text { hierarchically* }\end{array}$ & $\begin{array}{l}\text { No restrictions where you can use this } \\
\text { method }\end{array}$ \\
\hline $\begin{array}{l}\text { Level of complexity of the } \\
\text { application }\end{array}$ & $\begin{array}{l}\text { Simple calculation of results, } \\
\text { possible using Excel sheet }\end{array}$ & $\begin{array}{l}\text { Explanation of concept \& process to } \\
\text { management extremely challenging, } \\
\text { requires a specific software to calculate } \\
\text { results }\end{array}$ \\
\hline $\begin{array}{l}\text { Level of understanding of } \\
\text { specific problem }\end{array}$ & $\begin{array}{l}\text { Pair-wise comparison is a quite } \\
\text { artificial way of comparing a set of } \\
\text { items }\end{array}$ & $\begin{array}{l}\text { Ideal tool to gain deeper understanding } \\
\text { of a specific problem and its relation to } \\
\text { related factors }\end{array}$ \\
\hline Plausible results & $\begin{array}{l}\text { People usually agree with the out } \\
\text { coming priorities }\end{array}$ & $\begin{array}{l}\text { Verification of result due to feedback } \\
\text { loops and interrelations impossible }\end{array}$ \\
\hline
\end{tabular}

* The applications of AHP to complex decision situations have numbered in the thousands, and have produced extensive results in problems involving planning, resource allocation, priority setting, and selection among alternatives. Other areas have includedforecasting, total quality management, business process reengineering, quality function deployment, and the balanced scorecard.

Source: made on the basis of [20, 22].

Table 2

Characteristics of the proposed digital solutions

\begin{tabular}{|c|c|c|c|c|}
\hline Criteria & $\begin{array}{c}\text { Electronic document } \\
\text { management }\end{array}$ & RFID-system & GPS-tracking & Scanner-weight \\
\hline Cost of equipment, UAH & 77810 & 80121 & 7400 & 70000 \\
\hline $\begin{array}{c}\text { Influence on process } \\
\text { efficiency }\end{array}$ & significant & very significant & insignificant & significant \\
\hline $\begin{array}{c}\text { Impact on process } \\
\text { flexibility }\end{array}$ & very significant & very significant & very significant & significant \\
\hline $\begin{array}{c}\text { Influence on process } \\
\text { controllability }\end{array}$ & very significant & very significant & significant & very significant \\
\hline $\begin{array}{c}\text { Impact on process } \\
\text { reliability }\end{array}$ & significant & very significant & insignificant & significant \\
\hline $\begin{array}{c}\text { Impact on process } \\
\text { integration }\end{array}$ & very significant & very significant & very significant & significant \\
\hline
\end{tabular}

Source: own research.

According to the AHP method, one should perform the following sequence of actions:

Step 1. Build a matrix for determining the priorities of each criterion (Table 3).

Table 3

Determining the priority of each criterion

\begin{tabular}{|c|c|c|c|c|c|c|}
\hline & $\begin{array}{c}\text { The cost of } \\
\text { equipment }\end{array}$ & $\begin{array}{c}\text { Impact on } \\
\text { efficiency }\end{array}$ & Flexibility & $\begin{array}{c}\text { Controll- } \\
\text { ability }\end{array}$ & Reliability & Integration \\
\hline $\begin{array}{c}\text { The cost of } \\
\text { equipment }\end{array}$ & 1 & $1 / 7$ & $1 / 5$ & $1 / 4$ & $1 / 7$ & $1 / 7$ \\
\hline Impact on efficiency & 7 & 1 & 3 & 7 & 1 & 2 \\
\hline Flexibility & 5 & $1 / 3$ & 1 & 5 & $1 / 4$ & 1 \\
\hline Controllability & 4 & $1 / 7$ & $1 / 5$ & 1 & $1 / 7$ & $1 / 5$ \\
\hline Reliability & 7 & 1 & 4 & 7 & 1 & 3 \\
\hline Integration & 7 & $1 / 2$ & 1 & 5 & $1 / 3$ & 1 \\
\hline
\end{tabular}

Source: own research. 
The survey registered 15 local logistics operators of various sizes and researchers from 5 local universities - a total of 43 people were interviewed. The survey was conducted by questioning managers and scientists who evaluated the feasibility of each digital technology on the efficiency of logistics processes on a 10-point scale. The results of the questionnaire were summarized and the average score was determined accordingly. The analysis of the cost of digital technologies for implementation was determined according to the current digitalization programs offered on the domestic market and the cost of the necessary equipment [23-28].

The priority of each criterion is determined in the ratio between themselves on a scale from 1 to 9 following the increase in the priority of the criterion (in lines) over each other criterion. For example, the cost of equipment has a lower priority than other criteria, because when implementing digital technologies, the efficiency and reliability of the technology is more important. Similarly, the priority of digital proposals is determined in the context of each comparison criterion (Table 4).

Table 4

The matrix of priorities of the proposed digital solutions

\begin{tabular}{|c|c|c|c|c|}
\hline \multicolumn{5}{|c|}{ The cost of equipment } \\
\hline & $\begin{array}{l}\text { Electronic document } \\
\text { management }\end{array}$ & $\begin{array}{l}\text { RFID } \\
\text { system }\end{array}$ & $\begin{array}{c}\text { GPS } \\
\text { tracking }\end{array}$ & $\begin{array}{l}\text { Weight } \\
\text { scanner }\end{array}$ \\
\hline 1 & 2 & 3 & 4 & 5 \\
\hline Electronic document management & 1 & 0.33 & 0.14 & 0.25 \\
\hline RFID system & 3 & 1 & 7 & 3 \\
\hline GPS tracking & 7 & 0.14 & 1 & 0.33 \\
\hline Weight scanner & 4 & 0.33 & 3 & 1 \\
\hline Together & 15 & 2 & 11 & 5 \\
\hline \multicolumn{5}{|c|}{ Impact on efficiency } \\
\hline & $\begin{array}{l}\text { Electronic document } \\
\text { management }\end{array}$ & $\begin{array}{l}\text { RFID } \\
\text { system }\end{array}$ & $\begin{array}{c}\text { GPS } \\
\text { tracking }\end{array}$ & $\begin{array}{l}\text { Weight } \\
\text { scanner }\end{array}$ \\
\hline Electronic document management & 1 & 0.2 & 7 & 2 \\
\hline RFID system & 5 & 1 & 7 & 5 \\
\hline GPS tracking & 0.14 & 0.14 & 1 & 0.33 \\
\hline Weight scanner & 0.5 & 0.2 & 3 & 1 \\
\hline Together & 6.6 & 1.5 & 18 & 8.3 \\
\hline \multicolumn{5}{|c|}{ Flexibility } \\
\hline & $\begin{array}{l}\text { Electronic document } \\
\text { management }\end{array}$ & $\begin{array}{l}\text { RFID } \\
\text { system }\end{array}$ & $\begin{array}{c}\text { GPS } \\
\text { tracking }\end{array}$ & $\begin{array}{l}\text { Weight } \\
\text { scanner }\end{array}$ \\
\hline Electronic document management & 1 & 0.25 & 6 & 7 \\
\hline RFID system & 4 & 1 & 7 & 8 \\
\hline GPS tracking & 0.17 & 0.14 & 1 & 4 \\
\hline Weight scanner & 0.14 & 0.13 & 0.25 & 1 \\
\hline Together & 5.31 & 1.52 & 14.25 & 20 \\
\hline \multicolumn{5}{|c|}{ Controllability } \\
\hline & $\begin{array}{l}\text { Electronic document } \\
\text { management }\end{array}$ & $\begin{array}{l}\text { RFID } \\
\text { system }\end{array}$ & $\begin{array}{c}\text { GPS } \\
\text { tracking }\end{array}$ & $\begin{array}{l}\text { Weight } \\
\text { scanner }\end{array}$ \\
\hline Electronic document management & 1 & 4 & 0.2 & 0.25 \\
\hline RFID system & 0.25 & 1 & 3 & 0.33 \\
\hline GPS tracking & 5 & 0.33 & 1 & 0.33 \\
\hline Weight scanner & 4 & 3 & 3 & 1 \\
\hline Together & 10.25 & 8.33 & 7.20 & 1.92 \\
\hline \multicolumn{5}{|c|}{ Reliability } \\
\hline & $\begin{array}{l}\text { Electronic document } \\
\text { management }\end{array}$ & $\begin{array}{l}\text { RFID } \\
\text { system }\end{array}$ & $\begin{array}{c}\text { GPS } \\
\text { tracking }\end{array}$ & $\begin{array}{l}\text { Weight } \\
\text { scanner }\end{array}$ \\
\hline Electronic document management & 1 & 0.25 & 5 & 0.5 \\
\hline RFID system & 4 & 1 & 7 & 3 \\
\hline GPS tracking & 0.2 & 0.14 & 1 & 0.25 \\
\hline
\end{tabular}


Continuation Table 4

\begin{tabular}{|c|c|c|c|c|}
\hline 1 & 2 & 3 & 4 & 5 \\
\hline Weight scanner & 2 & 0.33 & 4 & 1 \\
\hline Together & 7.2 & 1.73 & 17 & 4.75 \\
\hline \multicolumn{5}{|c|}{ Integration } \\
\hline & $\begin{array}{l}\text { Electronic document } \\
\text { management }\end{array}$ & $\begin{array}{l}\text { RFID } \\
\text { system }\end{array}$ & $\begin{array}{l}\text { GPS } \\
\text { tracking }\end{array}$ & $\begin{array}{l}\text { Weight } \\
\text { scanner }\end{array}$ \\
\hline Electronic document management & 1 & 4 & 7 & 6 \\
\hline RFID system & 0.25 & 1 & 1 & 5 \\
\hline GPS tracking & 0.14 & 1 & 1 & 4 \\
\hline Weight scanner & 0.17 & 0.2 & 0.25 & 1 \\
\hline Together & 1.56 & 6.2 & 9.25 & 16 \\
\hline
\end{tabular}

Source: own development.

By analogy with Table 3, Table 4 takes into account the ratio of different decisions in the context of each criterion.

Step 2. Calculate the priority of each criterion and determine their amount (Table 5).

Table 5

The priorities of the criteria are calculated

\begin{tabular}{|c|c|c|c|c|c|c|}
\hline & $\begin{array}{c}\text { The cost of } \\
\text { equipment }\end{array}$ & $\begin{array}{c}\text { Impact on } \\
\text { efficiency }\end{array}$ & $\begin{array}{c}\text { Flexibilit } \\
\mathrm{y}\end{array}$ & $\begin{array}{c}\text { Controllabil } \\
\text { ity }\end{array}$ & $\begin{array}{c}\text { Reliabil } \\
\text { ity }\end{array}$ & $\begin{array}{c}\text { Integratio } \\
\mathrm{n}\end{array}$ \\
\hline The cost of equipment & 1 & 0.14 & 0.2 & 0.25 & 0.14 & 0.14 \\
\hline Impact on efficiency & 7 & 1.0 & 3 & 7 & 1.0 & 2 \\
\hline Flexibility & 5 & 0.33 & 1 & 5 & 0.25 & 1 \\
\hline Controllability & 4 & 0.14 & 0.2 & 1 & 0.14 & 0.2 \\
\hline Reliability & 7 & 1.0 & 4 & 7 & 1.0 & 3 \\
\hline Integration & 7 & 0.5 & 1 & 5 & 0.33 & 1 \\
\hline Together & 31 & 3 & 9 & 25 & 3 & 7 \\
\hline
\end{tabular}

Source: own development.

Step 3. Based on the received data on criteria priority we calculate the standardized values of criteria priority (Table 6).

Table 6

Matrix of standardized values of priority criteria

\begin{tabular}{|c|c|c|c|c|c|c|c|}
\hline & $\begin{array}{c}\text { The cost of } \\
\text { equipment }\end{array}$ & $\begin{array}{c}\text { Impact on } \\
\text { efficiency }\end{array}$ & Flexibility & Controllability & Reliability & Integration & $\begin{array}{c}\text { Priority } \\
\text { indicator }\end{array}$ \\
\hline $\begin{array}{c}\text { The cost of } \\
\text { equipment }\end{array}$ & 0.03 & 0.05 & 0.02 & 0.01 & 0.05 & 0.02 & 0.03 \\
\hline $\begin{array}{c}\text { Impact on } \\
\text { efficiency }\end{array}$ & 0.23 & 0.32 & 0.32 & 0.28 & 0.35 & 0.27 & 0.29 \\
\hline Flexibility & 0.16 & 0.11 & 0.11 & 0.20 & 0.09 & 0.14 & 0.13 \\
\hline Controllability & 0.13 & 0.05 & 0.02 & 0.04 & 0.05 & 0.03 & 0.05 \\
\hline Reliability & 0.23 & 0.32 & 0.43 & 0.28 & 0.35 & 0.41 & 0.33 \\
\hline Integration & 0.23 & 0.16 & 0.11 & 0.20 & 0.12 & 0.14 & 0.16 \\
\hline Together & 1 & 1 & 1 & 1 & 1 & 1 & \\
\hline
\end{tabular}

Source: own development. 


\section{O. A. Pokhylchenko, I. V. Flyk}

The standardized values of each criterion are calculated by dividing the values of each ratio by the sum of the the criterion priorities in the column (data from Table 5). The priority of each criterion is calculated as the ratio of the sum of standardized values in the line and the number of criteria:

$$
\text { Priority indicator }_{\text {cost }}=\frac{0.03+0.05+0.02+0.01+0.05+0.02}{6}=0.03
$$

According to the results obtained the most important criterion for choosing a digital solution is its impact on efficiency and reliability. while the least important ones are cost and controllability. The low importance of the cost of digital supply is due to the payback of digital technologies and the efficiency of their implementation.

Step 4. Form a matrix of standardized values of priority of digital solutions in a similar way (Table 7).

Table 7

Matrix of standardized values of decision priorities

\begin{tabular}{|c|c|c|c|c|c|}
\hline \multicolumn{6}{|c|}{ The cost of equipment } \\
\hline & $\begin{array}{l}\text { Electronic document } \\
\text { management }\end{array}$ & RFID system & GPS tracking & $\begin{array}{l}\text { Weight } \\
\text { scanner }\end{array}$ & $\begin{array}{c}\text { Priority } \\
\text { indicator xy }\end{array}$ \\
\hline 1 & 2 & 3 & 4 & 5 & 6 \\
\hline $\begin{array}{l}\text { Electronic document } \\
\text { management }\end{array}$ & 0.07 & 0.18 & 0.01 & 0.05 & 0.08 \\
\hline RFID system & 0.2 & 0.55 & 0.63 & 0.65 & 0.51 \\
\hline GPS tracking & 0.47 & 0.08 & 0.09 & 0.07 & 0.18 \\
\hline Weight scanner & 0.27 & 0.18 & 0.27 & 0.22 & 0.23 \\
\hline Together & 1 & 1 & 1 & 1 & \\
\hline \multicolumn{6}{|c|}{ Impact on efficiency } \\
\hline & $\begin{array}{l}\text { Electronic document } \\
\text { management }\end{array}$ & RFID system & GPS tracking & $\begin{array}{l}\text { Weight } \\
\text { scanner }\end{array}$ & $\begin{array}{c}\text { Priority } \\
\text { indicator xy }\end{array}$ \\
\hline $\begin{array}{l}\text { Electronic document } \\
\text { management }\end{array}$ & 0.15 & 0.1 & 0.39 & 0.24 & 0.23 \\
\hline RFID system & 0.75 & 0.6 & 0.39 & 0.6 & 0.6 \\
\hline GPS tracking & 0.02 & 0.1 & 0.06 & 0.04 & 0.05 \\
\hline Weight scanner & 0.08 & 0.1 & 0.17 & 0.12 & 0.12 \\
\hline Together & 1 & 1 & 1 & 1 & \\
\hline \multicolumn{6}{|c|}{ Flexibility } \\
\hline & $\begin{array}{c}\text { Electronic document } \\
\text { management }\end{array}$ & RFID system & GPS tracking & $\begin{array}{l}\text { Weight } \\
\text { scanner }\end{array}$ & $\begin{array}{c}\text { Priority } \\
\text { indicator } x y\end{array}$ \\
\hline $\begin{array}{l}\text { Electronic document } \\
\text { management }\end{array}$ & 0.19 & 0.16 & 0.42 & 0.35 & 0.28 \\
\hline RFID system & 0.75 & 0.66 & 0.49 & 0.4 & 0.58 \\
\hline GPS tracking & 0.03 & 0.09 & 0.07 & 0.2 & 0.1 \\
\hline Weight scanner & 0.03 & 0.08 & 0.02 & 0.05 & 0.04 \\
\hline Together & 1 & 1 & 1 & 1 & \\
\hline \multicolumn{6}{|c|}{ Controllability } \\
\hline & $\begin{array}{c}\text { Electronic document } \\
\text { management }\end{array}$ & RFID system & GPS tracking & $\begin{array}{l}\text { Weight } \\
\text { scanner }\end{array}$ & $\begin{array}{c}\text { Priority } \\
\text { indicator } x y\end{array}$ \\
\hline $\begin{array}{l}\text { Electronic document } \\
\text { management }\end{array}$ & 0.1 & 0.48 & 0.03 & 0.13 & 0.18 \\
\hline RFID system & 0.02 & 0.12 & 0.42 & 0.17 & 0.18 \\
\hline GPS tracking & 0.49 & 0.04 & 0.14 & 0.17 & 0.21 \\
\hline Weight scanner & 0.39 & 0.36 & 0.42 & 0.52 & 0.42 \\
\hline Together & 1 & 1 & 1 & 1 & \\
\hline
\end{tabular}




\begin{tabular}{|c|c|c|c|c|c|}
\hline 1 & 2 & 3 & 4 & 5 & 6 \\
\hline \multicolumn{6}{|c|}{ Reliability } \\
\hline & $\begin{array}{l}\text { Electronic document } \\
\text { management }\end{array}$ & RFID system & GPS tracking & $\begin{array}{l}\text { Weight } \\
\text { scanner }\end{array}$ & $\begin{array}{c}\text { Priority } \\
\text { indicator } x y\end{array}$ \\
\hline $\begin{array}{l}\text { Electronic document } \\
\text { management }\end{array}$ & 0.14 & 0.14 & 0.29 & 0.11 & 0.17 \\
\hline RFID system & 0.56 & 0.58 & 0.41 & 0.63 & 0.54 \\
\hline GPS tracking & 0.03 & 0.08 & 0.06 & 0.05 & 0.06 \\
\hline Weight scanner & 0.28 & 0.19 & 0.24 & 0.21 & 0.23 \\
\hline Together & 1 & 1 & 1 & 1 & \\
\hline \multicolumn{6}{|c|}{ Integration } \\
\hline & $\begin{array}{l}\text { Electronic document } \\
\text { management }\end{array}$ & RFID system & GPS tracking & $\begin{array}{l}\text { Weight } \\
\text { scanner }\end{array}$ & $\begin{array}{c}\text { Priority } \\
\text { indicator xy }\end{array}$ \\
\hline $\begin{array}{l}\text { Electronic document } \\
\text { management }\end{array}$ & 0.64 & 0.65 & 0.76 & 0.38 & 0.6 \\
\hline RFID system & 0.16 & 0.16 & 0.11 & 0.31 & 0.19 \\
\hline GPS tracking & 0.09 & 0.16 & 0.11 & 0.25 & 0.15 \\
\hline Weight scanner & 0.11 & 0.03 & 0.03 & 0.06 & 0.06 \\
\hline Together & 1 & 1 & 1 & 1 & \\
\hline
\end{tabular}

Source: own development.

The table shows that the introduction of the RFID system has the highest priority in terms of cost (0.59), efficiency (0.6), flexibility (0.58) and reliability (0.54). According to the criterion of controllability, the highest priority is given to the use of a scanner scale -0.42 . According to the criterion of integration, the highest priority is indicated by the introduction of the electronic document management system - 0.6.

The final decision on the use of a particular digital technology should be made based on the calculation of the overall priority for each decision. This indicator is calculated by adding the products of the priority of the decision according to a certain criterion and the priority of the criterion:

Priority $_{\mathrm{EDM}}=0.03 \times 0.08+0.29 \times 0.23+0.13 \times 0.28+0.05 \times 0.18+\ldots+0.33 \times 0.17+0.16 \times 0.6=0.27$.

Priority $_{\text {RFID system }}=0.03 \times 0.51+0.29 \times 0.6+0.13 \times 0.58+0.05 \times 0.18+\ldots+0.33 \times 0.54+0.16 \times 0.19=0.49$.

Priority $_{\text {GPS trackingu }}=0.03 \times 0.18+0.29 \times 0.05+0.13 \times 0.1+0.05 \times 0.21+\ldots+0.33 \times 0.06+0.16 \times 0.15=0.09$.

Priority $_{\text {scanner scale }}=0.03 \times 0.23+0.29 \times 0.12+0.13 \times 0.04+0.05 \times 0.42+\ldots+0.33 \times 0.23+0.16 \times 0.06=0.16$.

Therefore, it is necessary to implement the RFID system first, then to organize the application of the electronic document management system, then start using scanner scales and launch GPS system (Fig. 3).

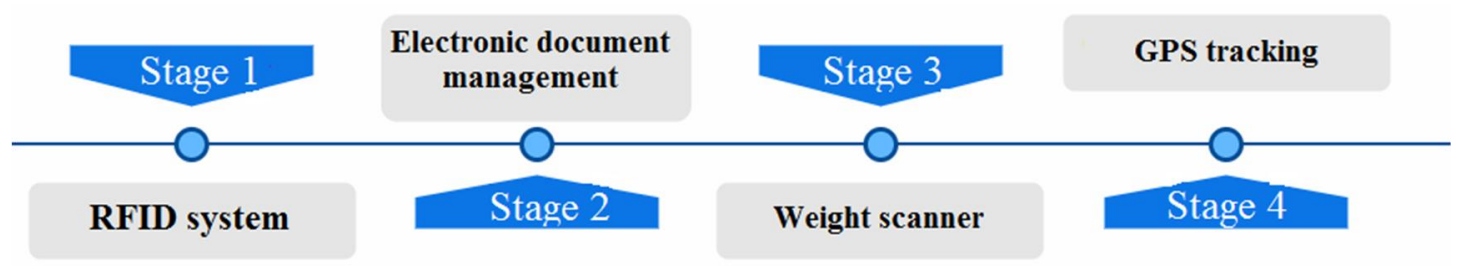

Fig. 3. The sequence of implementation of digital technologies at "UKR Logist" Ltd

Source: own development.

Following this sequence, the enterprise has the opportunity to decrease not only financial risks, but also risks associated with technical difficulties of the simultaneous launch of digital technologies. 


\section{O. A. Pokhylchenko, I. V. Flyk}

Conclusions

The study of theoretical and methodological aspects of the digitalization potential of logistics processes allows us to highlight the following main results:

- digital framework for logistical business especially in the field of logistics customer services have been further developed. It has been determined that the effective digital optimization of the processes of route formation, loading and unloading of vehicles, as well as storage and placement of goods in the warehouse is manifested primarily not only in decreasing the failures and errors at each stage, speeds up processes but also improves their quality. In particular, the article identifies and visualizes the key changes that the logistics operator delivering goods within the territory of Ukraine based on the implementation of a range of digitalization tools may deal with such as RFID-systems, GPS-trackers, scale scanners and electronic document management system.

- it was found that one of the most effective ways to build a digitalization plan for an enterprise or its individual business processes is application one of the multiple-criteria decision analysis (MCDA) methods, namely AHP. Due to the fact that AHP allows taking into account not only quantitative, but also qualitative expression of certain criteria to find an optimal solution, and at the same time requiring less costs and efforts comparing with similar methods of MCDA, the choice of AHP approach in this work made it possible to find the optimal sequence implementation of digital technologies at logistics operator. Thanks to this sequence, the enterprise has the opportunity to decrease not only financial risks, but also risks associated with technical difficulties of the simultaneous launch of digital technologies. Therefore, it is recommended to introduce the RFID system first. Then, the electronic document management should be launched. After that, it is recommended to introduce a scale scanner. Finally, the GPS system should be applied.

Thus, the results of this study can help many enterprises, in particular in the field of logistics, to more accurately assess the possibilities of digitalization of certain aspects of their activities. In particular, using the recommended algorithm for modeling the digitalization process and good visibility of key changes that may occur at the investigated logistics operator resulting from digitalization tools set implementation, will allow domestic logistics operators to make optimal decisions.

\section{Prospects for future research}

The prospects for the future research lie in the development and further deepening of knowledge about the applied aspects of improving the competitiveness of logistics operators based on the digitalization potential of logistics services.

1. Hagen R. (2018). The End of Ownership: Personal Property in the Digital Economy. Science and Public Policy, Vol. 45, Iss. 1, pp. 137-139. doi: 10.2966/scrip.140217.401.

2. Isaacson W. (2014). The Innovators: How a Group of Hackers, Geniuses, and Geeks Created the Digital Revolution. Simon \& Schuster; 1St Edition.

3. Scholz T. (2017). Uberworked and Underpaid: How Workers Are Disrupting the Digital Economy. Cambridge. UK: Polity Press.

4. Schwienbacher A. \& Larralde B. (2010). Crowdfunding of small entrepreneurial ventures. SSRN Electronic Journal, Available at: http://www.w-t-w.org/en/wp-content/uploads/2014/03/Schweinbacher-Larralde-2010.pdf

5. Toffler A. \& Toffler H. (2005). Revolutionary wealth. N. Y.: Knopf.

6. Andersson L., Van der Heyden L. (2017). Directing Digitalisation: Guidelines for Boards and Executives. Available at: http://www.thisfluidworld.com/wp-content/uploads/2017/02/Corporate-governance-February-2017.pdf.

7. Baberger V. (2017). Logistics 4.0 - Facing digitalizationdriven disruption. Available at: https://www.adlittle.com/sites/default/files/prism/logistics_section.pdf.

8. Galinska B., Kopania J., Walaszczyk A. (2017). Współczesne rozwiązania dla realizacji procesów logistycznych: Monografie Politechniki Łódzkiej. Łódź.

9. Magruk A. (2019). The Internet of things as the future technological trend of the innovative development of logistics. Poznan University of Technology. Vol. 6. No. 1. P. 15-24. Available at: https://www.wbc.poznan.pl/ Content/450994/download/. 


\section{Digitalization potential of logistics operator}

10. Бажал Ю., Бакуменко В., Бондарчук I. та ін. (2004). Інформаційна економіка. Роль інформації у формуванні ринкової економіки: монографія. за заг. ред. І. Розпутенка. К.: К.І.С, С. 33-57.

11. Кононова К. Ю. (2015). Інформаційна економіка: моделювання еволюційних процесів : монографія. Харків: ХНУ ім. В. Н. Каразіна.

12. Краус Н. М., Голобородько О. П., Краус К. М. (2018). Цифрова економіка: тренди та перспективи авангардного характеру розвитку. Ефективна економіка, № 1. Available at: ojs.dsau.dp.ua/index.php/efektyvnaekonomika/article/viewFile/997/862.

13. Krykavskyy Ye., Pokhylchenko O., Hayvanovych N. (2019). Supply chain development drivers in Industry 4.0 in Ukrainian enterprises. Oeconomia Copernicana, 10(2), pp. 273-290. doi: 10.24136/oc.2019.014.

14. Похильченко О. А. (2019). Тренди логістики та Supply Chain Management в проекції трансформаційних змін Industry 4.0. Інтелект XXI: наук.-екон. журнал”. К.: Вид. дім “Гельветика”. С. 149-154.

15. Крикавський С. В., Похильченко О. А., Фертч М. (2017). Логістика і управління ланцюгами поставок: навч. посіб. Львів: Видавництво Львівської політехніки.

16. Digital Transformation of Industries: In collaboration with Accenture. World Economic Forum. 2016. Available at: http://reports.weforum.org/digital-transformation/wp-content/blogs.dir/94/mp/files/pages/files/digitalenterprise-narrative-final-january-2016.pdf.

17. The digital transformation of logistics: Threat and opportunity. Available at: http://reports.weforum.org/ digital-transformation/the-digital-transformation-of-logistics-threat-andopportunity/?doing_wp_cron=1558383421.5034329891204833984375.

18. Franco L. A. \& Montibeller G. (2010). Problem structuring for multicriteria decision analysis interventions, Wiley Encyclopedia of Operations Research and Management Science. doi:10.1002/9780470400531.eorms0683.

19. Бродецкий Г. Л. (2009). Методы оптимизации многокритериальных решений в логистике. Москва: Available at: https://www.twirpx.com/file/1875261.

20. Görener A. (2012). Comparing AHP and ANP: An Application of Strategic Decisions Making in a Manufacturing Company, International Journal of Business and Social Science. Vol. 3, No. 11, pp. $194-208$.

21. Chung S., Lee A. H. I. \& Pearn W. L. (2005). Analytic network process (ANP) approach for product mix planning in semiconductor fabricator, Production Economics. Vol. 96, pp. 15-36.

22. Klaus D. Goepe (2011). AHP-ANP practical Application with Pros and Cons. 2011. Available at: https://bpmsg.com/ahp-anp-practical-application-with-pros-and-cons.

23. RFID-мітки для ідентифікації та автоматизації. Available at: https://www.vostok.dp.ua/ukr/catalog/ service/rfidmetki/.

24. RFID-принтери. Available at: https://atmaplus.com/printeru -etiketok/rfid-printeru. 1861-uhf/.

25. RFID-сканер Cipherlab 1861 (UHF). Available at: http://postorg.com.ua/product/rfid-schityvatel-cipherlab-

26. Автономный GPS маяк I 310 CIC D. Available at: https://gps-life.com/shop/gps-trekerymajaki/avtonomnyj-gps-majak-bi-310-

icada/?gclid=Cj0KCQjwrdjnBRDXARIsAEcE5YkSpg4d8X19cQ5ah_Rluz1J3p7MVcmtXJovbObOe7TI5j9Gf 0eCjFUaAvfeEALw_wcB.

27. Мобільні RFID-принтери. Available at: https://comtrade.ua/zebra-zq520-zq52-aun100e-00/.

28. Розрахунок вартості документообігу. Available at: https://fossdoc.com/individualcalculation.

1. Hagen R. (2018). The End of Ownership: Personal Property in the Digital Economy. Science and Public Policy, Vol. 45. Iss. 1, pp. 137-139. DOI: 10.2966/scrip.140217.401.

2. Isaacson W. (2014). The Innovators: How a Group of Hackers, Geniuses, and Geeks Created the Digital Revolution. Simon \& Schuster; 1 St Edition.

3. Scholz T. (2017). Uberworked and Underpaid: How Workers Are Disrupting the Digital Economy. Cambridge, UK: Polity Press.

4. Schwienbacher A. \& Larralde B. (2010). Crowdfunding of small entrepreneurial ventures. SSRN Electronic Journal. Retrieved from http://www.w-t-w.org/en/wp-content/uploads/2014/03/Schweinbacher-Larralde-2010.pdf

5. Toffler A. \& Toffler H. (2005). Revolutionary wealth. N. Y.: Knopf.

6. Andersson L. \& Van der Heyden L. (2017). Directing Digitalisation: Guidelines for Boards and Executives. Retrieved from http://www.thisfluidworld.com/wp-content/uploads/2017/02/Corporate-governance-February-2017.pdf.

7. Baberger V. (2017). Logistics 4.0 - Facing digitalizationdriven disruption. Retrieved from https://www.adlittle.com/sites/default/files/prism/logistics_section.pdf. 
8. Galinska B., Kopania J. \& Walaszczyk A. (2017). Współczesne rozwiązania dla realizacji procesów logistycznych [Contemporary solutions for the implementation of logistics processes]: monograph of Lodz Polytechnic, Lodz.

9. Magruk A. (2019). The Internet of things as the future technological trend of the innovative development of logistics. Poznan University of Technology, Vol. 6, No. 1, pp. 15-24. Retrieved from https://www.wbc.poznan.pl/ Content/450994/download/.

10. Bazhal Yu., Bakumenko V., Bondarchuk I. at al. (2004). Informatsiina ekonomika. Rol informatsii u formuvanni rynkovoi ekonomiky [Information economy. The role of information in the formation of a market economy]: a monograph. Kyiv: K.I.S., pp. 33-57.

11. Kononova K. (2015). Informatsiina ekonomika: modeliuvannia evoliutsiinykh protsesiv : monohrafiia [Information economy: modeling of evolutionary processes: monograph]. Kharkiv: V. N. Karazin Kharkiv National University.

12. Kraus N. M., Holoborodko O. P. \& Kraus K. M. (2018). Tsyfrova ekonomika: trendy ta perspektyvy avanhardnoho kharakteru rozvytku [Digital economy: trends and prospects of avant-garde development]. Efektyvna ekonomika. Retrieved from: ojs.dsau.dp.ua/index.php/efektyvna-ekonomika/article/viewFile/997/862.

13. Krykavskyy Ye., Pokhylchenko O., Hayvanovych, N. (2019). Supply chain development drivers in Industry 4.0 in Ukrainian enterprises. Oeconomia Copernicana, 10(2), pp. 273-290. DOI: 10.24136/oc.2019.014.

14. Pokhylchenko O. A. (2019). Trendy lohistyky ta Supply Chain Management v proektsii transformatsiinykh zmin Industry 4.0 [Trends in logistics and Supply Chain Management in the projection of transformational changes Industry 4.0] Naukovo-ekonomichnyi zhurnal "Intelekt XXI". "Helvetyka”, pp. 149-154.

15. Krykavskyi Ye. V., Pokhylchenko O. A. and Fertch M. (2017). Lohistyka i upravlinnia lantsiuhamy postavok [Logistics and supply chain management]. Lviv: NULP.

16. Digital Transformation of Industries: In collaboration with Accenture (2016). World Economic Forum. Retrieved from: http://reports.weforum.org/digital-transformation/wp-content/blogs.dir/94/mp/files/pages/files/digitalenterprise-narrative-final-january-2016.pdf.

17. The digital transformation of logistics: Threat and opportunity. Retrieved from: http://reports.weforum.org/ digital-transformation/the-digital-transformation-of-logistics-threat-and-opportunity/?doing_wp_cron=1558383421.

5034329891204833984375.

18. Franco L. A. \& Montibeller G. (2010) Problem structuring for multicriteria decision analysis interventions, Wiley Encyclopedia of Operations Research and Management Science. DOI:10.1002/9780470400531.eorms0683.

19. Brodetskiy G. L. (2009) Metodyi optimizatsii mnogokriterialnyih resheniy v logistike [Optimization methods for multicriteria solutions in logistics]. Moskva. Retrieved from https://www.twirpx.com/file/1875261.

20. Görener A. (2012) Comparing AHP and ANP: An Application of Strategic Decisions Making in a Manufacturing Company, International Journal of Business and Social Science, Vol. 3, No. 11, pp. 194-208.

21. Chung S., Lee A. H. I. \& Pearn W. L. (2005) Analytic network process (ANP) approach for product mix planning in semiconductor fabricator, Production Economics, Vol. 96, pp. 15-36.

22. Klaus D. Goepe (2011) AHP-ANP practical Application with Pros and Cons. Retrieved from https://bpmsg.com/ahp-anp-practical-application-with-pros-and-cons/

23. RFID-mitky dlia identyfikatsii ta avtomatyzatsii [RFID tags for identification and automation]. URL: https://www.vostok.dp.ua/ukr/catalog/service/rfidmetki/

24. RFID-pryntery. [RFID printers]. URL: https://atmaplus.com/printeru -etiketok/rfid-printeru

25. RFID-skaner Cipherlab 1861 (UHF). [RFID skanner Cipherlab 1861 (UHF)]. URL: http://postorg.com.ua/product/rfid-schityvatel-cipherlab-1861-uhf/

26. Avtonomnyi GPS maiak I 310 CIC D [Autonomous GPS beacon I 310 CIC D]. URL: https://gpslife.com/shop/gps-trekery-majaki/avtonomnyj-gps-majak-bi-310-

icada/?gclid=Cj0KCQjwrdjnBRDXARIsAEcE5YkSpg4d8X19cQ5ah_Rluz1J3p7MVcmtXJovbObOe7TI5j9Gf0eCjFUa AvfeEALw_wcB

27. Mobilni RFID-pryntery [Mobile RFID printers]. URL: https://comtrade.ua/zebra-zq520-zq52-aun100e-00/

28. Rozrakhunok vartosti dokumentoobihu [Calculation of the cost of document flow]. URL: https://fossdoc.com/individualcalculation. 
О. А. Похильченко, І. В. Флик Національний університет “Львівська політехніка”, кафедра маркетингу і логістики

\title{
ПОТЕНЦІАЛ ДІДЖИТАЛІЗАЦІЇ ЛОГІСТИЧНОГО ОПЕРАТОРА
}

\author{
() Похильченко О. А., Флик I. В., 2020
}

Досліджено методологічні аспекти управління процесом логістичного обслуговування кліснтів підприємств під кутом удосконалення потенціалу його диджиталізації. Встановлено, що потенціал оцифрування логістичних процесів знаходить вияв, насамперед, у підвищенні швидкості та ефективності управління, можливості свосчасного коригування загроз і ризиків, які виникають, та у полегшенні аналітичного опрацювання та точнішого оцінювання великих масивів інформації. 3 метою виявлення потенціалу диджиталізації процесу логістичного обслуговування підприємства на прикладі діяльності логістичного оператора, що здійснюс доставку вантажів на території України, змодельовано ключові зміни, які можуть виникнути на підприємстві на основі імплементації комплексу заходів щодо упровадження засобів диджиталізації.

Ключові слова: диджитал-технології; логістичне обслуговування; AHP-аналіз; RFID система; GPS система. 